\title{
The Processing of Golden Snail (Pomacea canaliculata) to Reduce Level of Heavy Metal Lead (Pb) and Cadmium (Cd)
}

\author{
Ade Gunawan ${ }^{1}$, Achyani $^{2}$, Muhfahroyin $^{3}$, Widya Sartika Sulistiani $^{4}$, Hening Widowati ${ }^{5}$ \\ \{adeguns89@gmail.com¹, acysbd@gmail.com², muhfahroyin@yahoo.com³ \\ widya.sulistiani@gmail.com ${ }^{4}$, hwummetro@gmail.com $\left.{ }^{5}\right\}$ \\ Biology Education, Postgraduate Program, University of Muhammadiyah Metro, Lampung - \\ Indonesia ${ }^{1,2,3,5}$ \\ Biology Education, Faculty of Teacher Training and Education, University of Muhammadiyah Metro, \\ Lampung - Indonesia ${ }^{4}$
}

\begin{abstract}
The decline of environmental quality has an impact on the high accumulation of heavy metals in the organs of aquatic biota such as the golden snail (Pomacea canaliculata). Food processing before consumption is expected to reduce the levels of heavy metals in golden snail's meat. This study aims to take a look at the effect of golden snail meat processing methods on reducing levels of heavy metals $\mathrm{Pb}$ and $\mathrm{Cd}$. The research method is an experiment with processing, namely steaming, boiling, frying. The results of ANOVA show that there is an effect of processing methods on reducing levels of heavy metals. It is shown with the significance value (sig.) $0,000<\alpha=0,05$. The highest decline of heavy metasl content was in boiling process with a reducing percentage in $\mathrm{Pb}$ content of $44.39 \%$, and $\mathrm{Cd}$ content of $43.30 \%$.
\end{abstract}

Keywords: Golden Snail Processing, Reduce, $\mathrm{Pb}, \mathrm{Cd}$

\section{Introduction}

People's way of life which ignores the environment increases the pollution. For example, water pollution caused by various dangerous chemical intake into the water. These chemical substances come from industrial wastes, household wastes, vehicle exhaust, plastic wastes, pesticides, and chemical fertilizer. Heavy metals such as $\mathrm{Cd}$ and $\mathrm{Pb}$ are usually produced as chemical factories wastes, electroplating activities, and household wastesn [1]. Overused of chemical fertilizer and vehicles emission are also contribute to heavy metal pollution in the environment [2]. Pesticides used in farming location get into water through irrigation and move into other land in other location through runoff [3]. Those situation increase the heavy metal content in the water followed by the accumulation inside the aquatic biota, such as 
golden snail. Heavy metals found in the mollusc correlate significantly with those found in the water [4].

Golden snail is actually worthless fishery product, but based on the proximate test it has a high level of protein content [5]. The research showed that golden snail has $21.34 \%$ of protein, $2.28 \%$ of fat, $6.63 \%$ of fiber, $14 \%$ of ashes, $29.33 \%$ of calcium, and $0.13 \%$ of phosphor [6]. Almost all of essential amino acid contained in the golden snail are fulfilled the recommended ideal protein pattern. Its proportion of unsaturated fatty acids is higher than the saturated one, which is $39.5 \%$ [7]. Nevertheless, mollusk are the most efficient and proper bioindicator for heavy metal pollution since it can accumulate the pollutant without killing itself [8]. The slow movement of golden snail, its lifestyle in the bottom of the water, and its ability to be a filter feeder result in the increasing of heavy metal contained in this organisms. If they are consumed by human, it can be dangerous since there will be a biomagnification of the heavy metal inside the human body and disturb the metabolism system.

$\mathrm{Pb}$ metal can get into the human body through respiration, food, and beverages [9]. The small amount of heavy metals can be accumulated inside human body. Finally, it will cause a negative effect and healthy problem [10]. The accumulated heavy metals inside the tissue, if more than the tolerable intake, can be poisonous since it is carcinogenic.

Food and Agricultural Organization/World Health Organization (FAO/WHO) declare that provisional tolerable intake (PTWI) for Pb inside human body is $25 \mu \mathrm{g} / \mathrm{kg}$ of body weight (equals to $1500 \mathrm{mg} / \mathrm{g} / \mathrm{wk}$ for a-60 $\mathrm{kg}$-man [11], while for $\mathrm{Cd}$ is $7 \mu \mathrm{g} / \mathrm{kg}$ of body weight [12]. Moreover, food processing can reduce the pollutant contained. A proper food processing can decrease the heavy metal contained inside the food before consumed [13]. Furthermore, processing the food from animal sources can also kill the pathogens inside them. Decreasing of Cd is affected by the washing frequency and boiling time [14], while steaming, boiling and stir-frying can reduce the $\mathrm{Pb}$ and $\mathrm{Cd}$ content inside the leaves and fruit of long beans [13]. A similar result is also found in animal-source food such as golden snail, since animal tissues are more easily damaged for the absence of the cell wall. The boiling process damages the plasm membrane as well as the organelle's membranes so the heavy metal can easily escape from the tissues.

Based on those facts, this research aims to look find out the most effective way from various processing of golden snail (Pomacea canaliculata) to reduce its heavy metal content $(\mathrm{Pb}$ and $\mathrm{Cd})$.

\section{Method}

The research is started by conducting a survey along the river flow started from Way Raman 36 Kalibening, Pekalongan,East Lampung to DAM Raman, Purwoasri, North Metro, Metro City, Lampung Province, Indonesia, which is indicated polluted by heavy metals. The research design used is Completed Randomized Design (CRD) with a Purposive Sampling methods. Golden snail meats are processed in various ways: steamed, boiled, and stir fried. There is also unprocessed golden snail meat as control. The measurement of heavy metal content used is Vogel's Spectrophotometer UV-Vis method followed by Two-Way Variance Analysis to determine the significance of various processing of golden snail meats on $\mathrm{Pb}$ and Cd content decreasing. The research was done in $1^{\text {st }}$ May $-20^{\text {th }}$ June 2018. 


\section{Results and Discussion}

\subsection{The Profile of heavy metals in the water, sediment, and biota.}

DAM Raman is the riverbank of Way Raman with 24ha wide and an artificial reservoir that equipped by irrigation infrastructures [15]. Moreover, it also plays a role as conservation ecotourism area. Agricultural land around that site contributes to heavy metals pollution into the water. Following histogram (Fig. 1) shows the heavy metals content in the water, sediment, and golden snails taken from the research area.

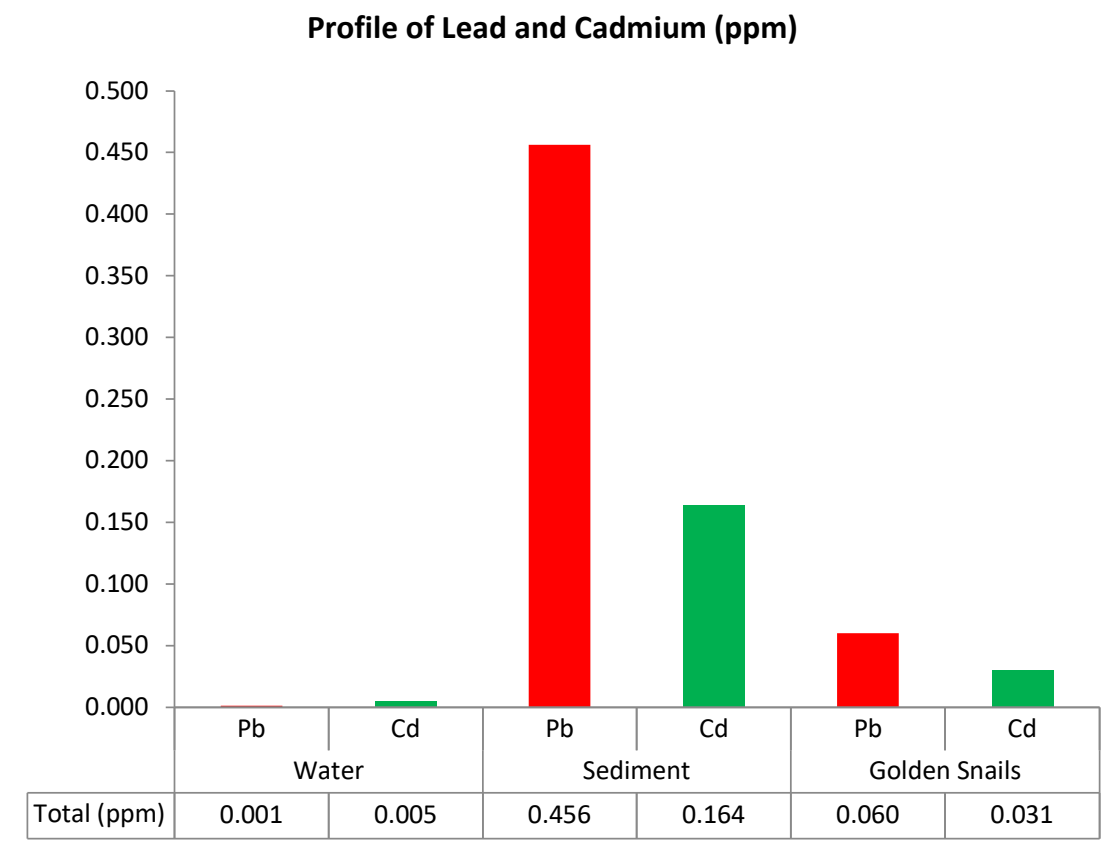

Fig 1. The Comparison of Heavy Metals Content (PB and Cd) in the Water, Sediment, and Golden Snails taken in the Research Area

Figure 1 shows that the heavy metals $(\mathrm{Pb}$ and $\mathrm{Cd})$ contents in the water respectively are $0.001 \mathrm{ppm}$ and $0.005 \mathrm{ppm}$, while in the sediment are $0.456 \mathrm{ppm}$ and $0.164 \mathrm{ppm}$, and inside the biota (golden snail) are $0.060 \mathrm{ppm}$ and $0.031 \mathrm{ppm}$. Those numbers are still below the threshold based on NOAA (National Oceanic and Atmospheric Administration), US department of Commerce, which is 30.240 ppm [16]. Meanwhile, the Cd threshold set by KepMen LH no 51 year 2004 is 0.47 ppm [17]. Likewise, based on CCME (Canadian Council of Ministers for the Environment), the $\mathrm{Pb}$ threshold in the sediment is $30.2 \mathrm{ppm}$ and $\mathrm{Cd}$ is 0.7 ppm [18].

However, those numbers still need to be watched since heavy metals are easily bind organic matters, especially in filter feeder process when the food get inside the biota bodies 
and biomagnification is happened. So that, the more filtered food, the more accumulated heavy metals are inside the water biota.

\subsection{The Profile of heavy metals ( $\mathrm{Pb}$ and $\mathrm{Cd}$ ) in the golden snails meats due to processing factors.}

The profile of $\mathbf{P b}$ content. The following histogram (Fig. 2) shows the decreasing of $\mathrm{Pb}$ content in various processing ways.

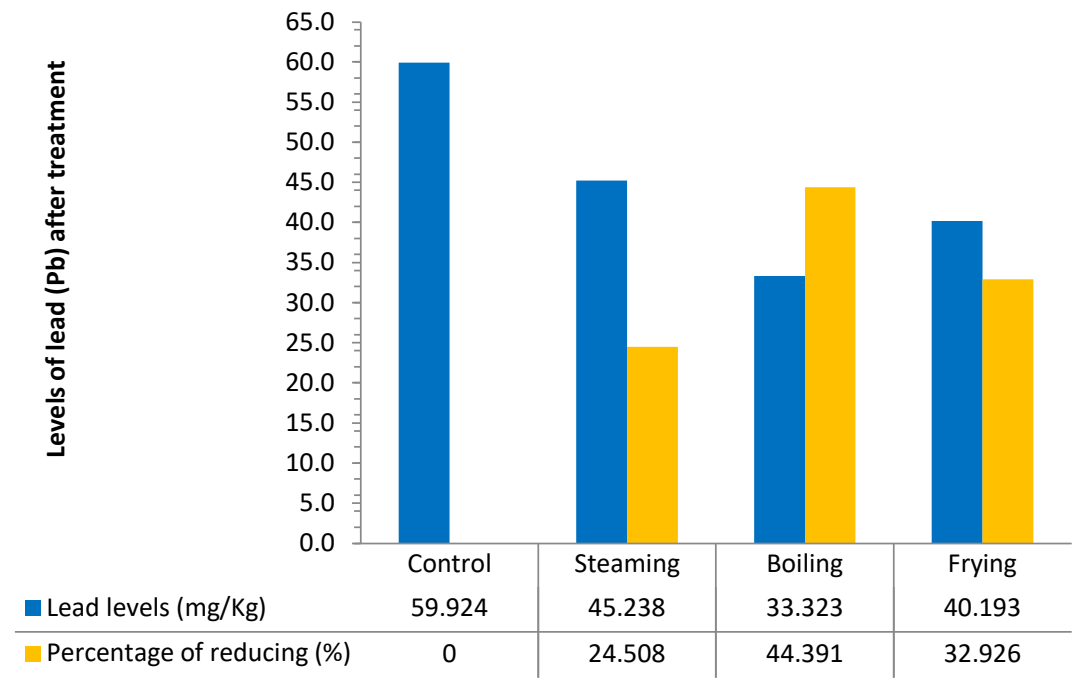

Fig 2. The Pb Content Decreasing (Percentage) in Various Processing Methods

Figure 2 depicts that the percentage of $\mathrm{Pb}$ content decreasing are different in various processing methods. By boiling, the percentage decreases for $44.39 \%$; stir frying for $32.92 \%$; and steaming for $24.50 \%$. It can be seen that boiling is the most effective processing methods to decrease the $\mathrm{Pb}$ content, if conversed into ppm it equals to $0.0333 \mathrm{ppm}$ of $\mathrm{Pb}$ content trace. It is followed by stir frying $(0.0401 \mathrm{ppm})$ and steaming $(0.0452 \mathrm{ppm})$.

The Profile of Cd content. This following histogram (Fig. 3) shows the decreasing of $\mathrm{Cd}$ content in various processing methods. 


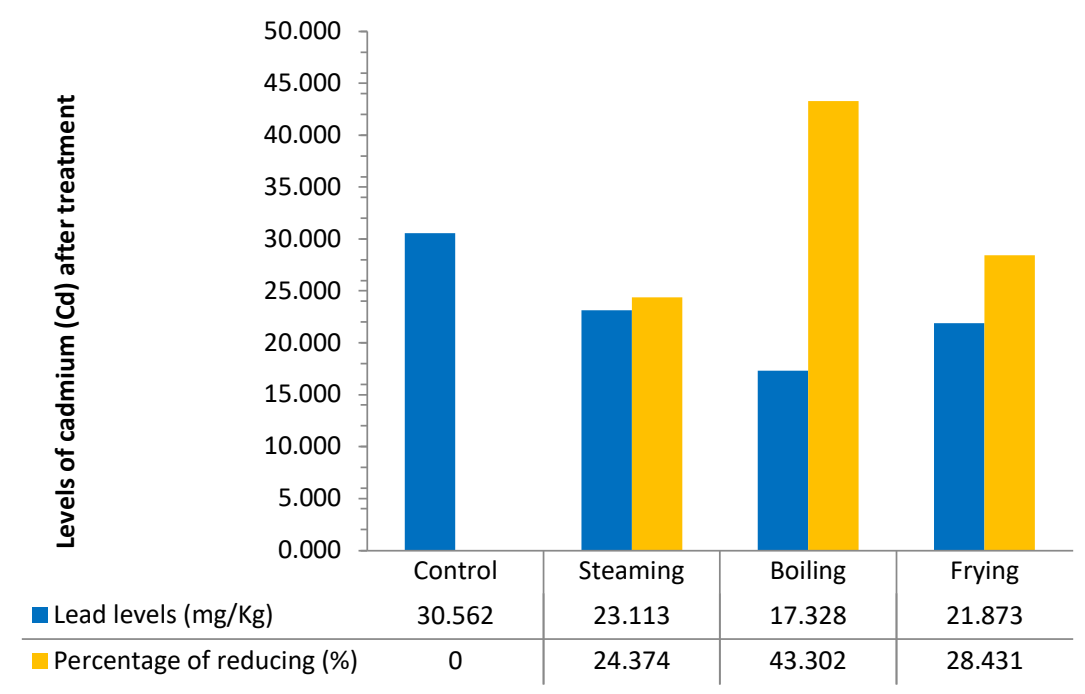

Fig 3. The Decreasing of Cd Content (Percentage) in Various Processing Methods.

Figure 3 shows that there is a decreasing of $\mathrm{Cd}$ content (percentage) in various processing methods. Boiling, stir frying, and steaming methods present these decreasing percentage respectively: $43.30 \%, 28.43 \%$, and $24.37 \%$. So, the most effective processing method is boiling, which only $0.0173 \mathrm{ppm}$ of traced $\mathrm{Cd}$. This number following by $0.0218 \mathrm{ppm}$ (stir frying) and $0.0213 \mathrm{ppm}$ (steaming).

\subsection{The effect of various processing methods on the decreasing of $\mathrm{Pb}$ and $\mathrm{Cd}$ content.}

The result of ANOVA test shows a significant decreasing of $\mathrm{Pb}$ and $\mathrm{Cd}$ content in golden snail meats (Pomacea canaliculata) due to various methods of food processing $(0,000<\alpha=$ $0,05)$. The processing methods are important techniques that should be done to reduce the heavy metal pollution content inside the food. These methods also can kill pathogenic microorganisms that endanger to the human body. Through certain processing methods, some toxic substances inside the food can be reduced or omitted completely. Commonly, high temperature is used to preserve food and exempt it from microbes [19].

The decreasing of $\mathrm{Pb}$ and $\mathrm{Cd}$ content is caused by the temperature used in food processing process that reach $100^{\circ} \mathrm{C}$. The heat used in the process releases the bound heavy metals from the golden snail meats. In steaming process (B), the hot water vapors used in the process degrade the volatile heavy metals inside the golden snail meats and release them. Heating process can increase evaporation and chemical hydrolysis or degradation, so that decreases the residue level [20]. Meanwhile, boiling is the best and the most effective to reduce the $\mathrm{Pb}$ and $\mathrm{Cd}$ content in golden snail meats compare to two other process, steaming and stir frying. It is shown that $\mathrm{Pb}$ residue is only $0.0333 \mathrm{ppm}$ (44.39\% of decreasing) and $\mathrm{Cd}$ residue is 0.0173 ppm $(43.30 \%)$. Those low numbers are caused by boiling process, since the golden snail meats directly contact to boiling water $\left( \pm 100^{\circ} \mathrm{C}\right)$ so that the high temperature spread evenly to the whole meat parts. The boiling water infiltrate the cell membrane by diffusion and dissolve the accumulated heavy metals within the tissues. Those numbers are also under the threshold 
determined by the government (SNI) that is $1.5 \mathrm{mg} / \mathrm{kg}$ for $\mathrm{Pb}$ and $1.0 \mathrm{mg} / \mathrm{kg}$ for $\mathrm{Cd}$. Nevertheless, it is still dangerous if they are consumed by human continuously since $\mathrm{Pb}$ is hard to be unraveled and can accumulated within the body [21].

The heavy metals like $\mathrm{Pb}$ and $\mathrm{Cd}$ are highly toxicity to human body. Lead can inhibit the hemoglobin $(\mathrm{Hb})$ formation process thus can trigger anemic condition, central or peripheral nervous system disruption, renal and reproduction system disruption, imbecile in children, epilepsy, skeletal defects, and somatic cells disruption [22]. Lead that get into bloodstream can cause hypertension, increase the reactive oxygen species (ROS) production. ROS is a derivative of oxygen reacting to electron. Main source of ROS is cellular respiration and metabolism process [23].

The golden snails taken from DAM Raman waters after boiling process can be consumed 50.17 gr per week at most for a-60-kilo man, based on Pb Maximum Tolerable Intake (MTI) value. Moreover, based on Cd MTI value, the same man can consume up to 44.35 gram of golden snail meats per week.

The processing of golden snail meats is commonly conducted by people, such as boiling before trading in traditional market. Usually, the boiling process is done in order to ease the split the meat from its shell [24]. As mentioned before, it turns out that the heating process can also disrupt the plasm and organelle membranes, thus the heavy metals can be released easier from the tissue [25]. Besides cooking processes, washing and soaking using various types of lime and orange can also significantly reduce the lead and chromium content up to tolerant intake.

\section{Conclusion}

The cooking process of golden snail (Pomacea canaliculata) affects the declining of heavy metal content $(\mathrm{Pb}$ and $\mathrm{Cd})$. This is shown statistically by value of sig. $0.000<\alpha=0.05$. The most effective method is boiling, which reduce the $\mathrm{Pb}$ content as much as $44.39 \%$, and $43.40 \%$ for $\mathrm{Cd}$. Those percentages equal to $\mathrm{Pb}$ residue of $0.0333 \mathrm{ppm}$ and $\mathrm{Cd}$ residue of $0.0173 \mathrm{ppm}$.

\subsection{Acknowledgements}

The authors would like to express their sincere appreciation to the Ministry of Research, Technology, and Higher Education for its funding this research in the Student Thesis Research scheme.

\section{References}

[1] B. P. W. Raymond N. Yong, A. M. O. Mohamed, Principles of Contaminant Transport in Soils (developments in geotechnical engineering). Elsevier Science Ltd, 1992.

[2] T. Notohadiprawiro, Heavy Metals in Agriculture. Yogyakarta: Geology, Gadjah Mada University, 2016.

[3] D. J. Puspitasari, "Kajian bioremediasi pada tanah tercemar pestisida," Kovalen, vol. 2, no. 3, pp. $98-106,2016$

[4] T. G. Krupnova, I. V. Mashkova, A. M. Kostryukova, E. E. Schelkanova, and S. V. Gavrilkina, "Gastropods as potential biomonitors of contamination caused by heavy metals in South Ural lakes, Russia," Ecol. Indic., 2018, doi: 10.1016/j.ecolind.2017.12.005. 
[5] A. Mualim, S. Lstai, and S. Hanggita, "Kandungan gizi dan karakteristik mi basah dengan substitusi daging keong mas (Pomacea canaliculata) (," Fistech, 2013.

[6] M. A. P. La Ode Nafiu, "PEMBERIAN keong mas (Pomacea sp) dalam pakan terhadap penampilan itik bali dan itik tegal," Agriplus, vol. 20, no. 1, pp. 36-41, 2010.

[7] S. Ghosh, C. Jung, and V. B. Meyer-Rochow, "Snail as mini-livestock: Nutritional potential of farmed Pomacea canaliculata (Ampullariidae)," Agric. Nat. Resour., 2017, doi: 10.1016/j.anres.2017.12.007.

[8] N. S. H. Caturi Andin Widiyanti, Sunarto, "Kandungan Logam Berat Timbal (Pb) serta Struktur Mikroanatomi Ctenidia dan Kelenjar Pencernakan (Hepar) Anodonta woodiana Lea., di Sungai Serang Hilir Waduk Kedung Ombo," BioSMART, vol. 7, no. 2, pp. 136-142, 2005.

[9] Titin Agustina, "Kontaminasi logam berat pada makanan dan dampaknya pada kesehatan," Teknobuga, vol. 1, no. 1, pp. 51-65, 2014.

[10] E. Naria, "Mewaspadai Dampak Bahan Pencemar Timbal (Pb) di Lingkungan Terhadap Kesehatan," J. Komun. Penelit., 2005.

[11] I. Hananingtyas, "Studi Pencemaran Kandungan Logam Berat Timbal (Pb) dan Kadmium (Cd) pada Ikan Tongkol (Euthynnus sp.) di Pantai Utara Jawa," BIOTROPIC J. Trop. Biol., 2017, doi: 10.29080/biotropic.2017.1.2.41-50.

[12] N. W. Fahmy Barik, Norma Afiati, "KAJIAN kandungan natrium (Na) dan logam berat timbal $(\mathrm{Pb})$ pada jaringan lunak kerang darah (Anadara granosa (L.)) dari Perairan Tanjung Emas Semarang Dan Perairan Wedung Demak," DIPONEGORO J. MAQUARES, vol. 3, no. 1, pp. 151-159, 2014.

[13] A. S. Hening Widowati, Widya Sartika Sulistiani, "Pengaruh proses pengolahan terhadap kadar logam berat dan kadar gizi pada kacang panjang," BIOEDUKASI Biol. Educ. J., vol. 8, no. 2, pp. 172-275, 2017.

[14] A. H. Dewa Ayu Trisna Budiari, I. G. A. Lani Triani, "Pengaruh frekuensi pencelupan dan lama perebusan terhadap kadar logam berat dan mutu sensoris sawi hijau (Brassica rapaI. Subsp. Perviridis Bayley)," J. REKAYASA DAN Manaj. AGROINDUSTRI, vol. 4, no. 1, pp. 52-61, 2016.

[15] Yudianto, Desain Sistem Pengelolaan Kawasan Ekowisata Dam Raman Berkelanjutan (Studi Prospektif Pencegahan Potensi Konflik Di Masyarakat Dalam Pengelolaan Sumber Daya Alam). Lampung: LPPM : IAIN Metro, 2015.

[16] K. Arisandy, E. Herawati, and E. Suprayitno, "Akumulasi Logam Berat Timbal $(\mathrm{Pb})$ dan Gambaran Histologi pada Jaringan Avicennia Marina (Forsk.) Vierh di Perairan Pantai Jawa Timur," J. Fish. Mar. Res., 2012.

[17] S. M. Indrawati, "Pencemaran logam berat pb dan cd dan keluhan kesehatan pada masyarakat di Kawasan Pesisir Belawan," Jumantik, vol. 2, no. 2, pp. 54-60, 2017, doi: 10.30829/jumantik.v2i2.1165.

[18] E. S. Heru Setiawan, "Konsentrasi logam berat pada air dan sedimen di Perairan Pesisir Provinsi Sulawesi Selatan," Indones. For. Rehabil. J., vol. 3, no. 1, pp. 67-79, 2015.

[19] S. Imam Supardi, Mikrobiologi dalam pengolahan dan keamanan pangan. Bandung: Alumni: Alumni, 1999.

[20] M. R. P. Dinanti, I. G. A. L. Triani, and I. K. Satriawan, "Pengaruh Perlakuan Pencucian Dan Perebusan Terhadap Kadar Residu Insektisida Klorpirifos Dan Karakteristik Kacang Panjang (Vigna Sinensis)," J. REKAYASA DAN Manaj. AGROINDUSTRI, 2015.

[21] M. Paundanan, "Kontaminasi Logam Berat (Hg Dan Pb) Pada Air, Sedimen Dan Ikan Selar Tetengkek (Megalaspis Cordyla) Di Teluk Palu Provinsi Sulawesi Tengah,” Institut Pertanian Bogor, 2015.

[22] R. P. Dewa, "Analisa kandungan timbal $(\mathrm{Pb})$ dan kadmium $(\mathrm{Cd})$ pada air minum dalam kemasan di Kota Ambon," Maj. BIAM, 2015.

[23] S. T. Ambarwanto, N. Nurjazuli, and M. Raharjo, "Hubungan Paparan Timbal Dalam Darah dengan Kejadian Hipertensi Pada Pekerja Industri Pengecoran Logam Di Ceper Klaten Tahun 2015," J. Kesehat. Lingkung. Indones., 2016, doi: 10.14710/jkli.14.2.35-39.

[24] T. E. Sulthan Alfathir, "Inovasi pengelolaan hama keong mas (pomacea canaliculata lamarck) 
menjadi produk keripik keong mas polita di CV Polita Nusantara," J. Pangan dan Agroindustri, vol. 6, no. 1, pp. 80-89, 2018.

[25] M.Z. Hilmi, F. Swastawati, A. P. Anggo "Pengaruh perendaman berbagai jenis jeruk terhadap kandungan logam berat timbal $(\mathrm{Pb})$ DAN KROMIUM $(\mathrm{Cr})$ pada kerang hijau (Perna viridis Linn)," J. Pengolah. dan Bioteknol. Has. Perikan., 2017. 